\title{
Student perceptions of staff in the Information Commons: a survey at the University of Sheffield
}

\author{
Rachel Bickley \\ Library Services, University of the West of England, Bristol, UK \\ Sheila Corrall \\ Information School, University of Sheffield, Sheffield, UK
}

\begin{abstract}
Purpose - Technology has transformed teaching and learning environments in tertiary education, introducing new collaborative library spaces and developing the roles and skills of library staff. Academic libraries need continually to re-examine their services to ensure they meet student needs. The current survey aimed to discover how students perceived staff in the Information Commons (IC) and whether their perceptions of staff attitudes and skills influenced their use of library resources.

Design/methodology/approach - A questionnaire containing closed and open questions was distributed electronically to undergraduate and postgraduate students at the University of Sheffield, obtaining 250 responses (c1\% of the student population).

Findings - The results showed that most students were unable to distinguish different groups of staff, were unaware of their departmental librarian and did not recognise the academic role of librarians. However, those who had sought assistance in the IC or attended classes delivered by librarians had positive views of their experiences.
\end{abstract}

Research limitations - The timing and fixed duration of the study limited the size and nature of the sample, the generalizability of the findings and depth of the investigation, but sufficient data were collected to establish patterns of behaviour and identify important factors.

Practical implications - Low awareness among students of the expertise of librarians and their capacity to provide academic support indicates a need for more promotion to ensure library resources are properly utilised.

Originality/value - The study is thought to be the first of its kind conducted in the UK and the only such survey carried out in an Information Commons setting.

Keywords Academic libraries, Information commons, Librarians, Reference services, Student perceptions, University libraries

Paper type Research paper

\section{Introduction}

The context in which academic libraries operate is changing. Technology now plays a significant role in higher education (Bodnar, 2009), and learning and teaching styles have shifted from classroom-based learning to more collaborative methods, partially influenced by the development of technology that facilitates such activities, but also due to a movement towards models of active, student-centred learning (Bennett, 2005; Roberts, 2007; Whitchurch, 2006). This has impacted upon academic libraries, which must provide spaces and resources to facilitate this kind of studying (MacWhinnie, 2003). Additionally, students are beginning to see themselves as customers of the institution and, "seeking a return on their own financial investment in their education", expect their money's worth from the library (Norry, 2003, p. 58; Robinson and Reid, 2007). 
These demands have impacted upon library staff. With technology playing an increasing role, a new dimension of knowledge is required from staff (Boyd, 2008; Whitchurch, 2006). Roles may become blurred (Abson, 2003), as many libraries notice a decrease in reference enquiries and an increase in technical queries (Franks, 2008). In response to the way in which technology has become integrated into the library and the resultant rise in requests for technical assistance, some academic libraries have merged with their institution's IT service, allowing students to access both library and computing service staff in the same building (Brophy, 2005; Franks, 2008; Whitchurch, 2006). This has resulted in staff with a wider range of roles working on the information and enquiry desks in many academic libraries (Boyd, 2008; Norry, 2003). The role of librarians as teachers has also developed significantly and expanded into the online classroom, represented by the institutional course management system or virtual learning environment (Bewick and Corrall, 2010; Donaldson, 2010; York and Vance, 2009).

As academic libraries have been re-designed to meet the trends in higher education, some have been transformed into technology-rich environments known as "information commons" (Held, 2009, p. 190). The idea that students can complete their work from preliminary research to producing the final product in one place is one of the main notions of the information commons (Bodnar, 2009; Whitchurch, 2006). Thus, software and electronic resources, multimedia laboratories and production facilities, spaces for social and collaborative learning, print collections and reference services are brought together in one physical space (Beagle, 1999; Cowgill et al., 2001; MacWhinnie, 2003; Whitchurch, 2006). This merging of services and resources impacts upon library staff as the library space becomes "a campus production hub" (Zink et al., 2010, p. 114) and the staff body develops into a "multi-dimensional" entity (Boyd, 2008, p. 234).

It is vital that academic libraries "continually re-examine" whether they are offering the services and resources that students need and desire (Brophy, 2005, p. 60; MacWhinnie, 2003). Investigating student perceptions of library staff is one way of assessing how well the service is being delivered, as well as a means of evaluating its quality and relevance. With the impact that the widened scope of provision in modern academic libraries has had on the roles and expertise of library staff, understanding student perceptions of the staff can also contribute to an awareness of how well new library models are working.

There have been several studies of student perceptions of academic library staff, notably Hernon and Pastine's (1977) widely-cited investigation and similar more recent (though much smaller) surveys carried out by Fagan (2003) and Luzius and Noe (2003), but none conducted in an information commons (IC) setting. Others have researched more specific aspects: Chiu (2000) and Lo (2004) both examined student attitudes towards the reference role of librarians, while Polger and Okamoto (2010) investigated student opinions of their teaching role, all in traditional library environments. Previous studies have examined how students perceive the skills, knowledge and manner of academic librarians and other library staff, the extent to which students distinguish between different roles and the ways in which these perceptions may impact upon use of the library, all of which helped to frame the research questions for the present study.

The originality of our investigation lies particularly in its contemporary IC setting. A few surveys in institutions with information or learning commons have put down some markers on student perceptions of staff and their roles, but have provided only limited insights as their focus was on student use of and satisfaction with services (Gardner and Eng, 2005; 
Fitzpatrick et al., 2008; Moore and Wells, 2009); in another case, the focus was on study behaviour and the survey was deliberately aimed at infrequent/non-users of the library (Vondracek, 2007). The level of investment in "commons" facilities with their radical reconfiguration of academic support services demonstrates the importance of the phenomenon and creates an urgent need to revisit problems defined by previous research in the current changed library and learning environment. Continuing advances in the technologies that pervade such settings also offer opportunities to suggest new up-to-date ideas for handling issues arising from the investigation.

The study also breaks new ground in being the first of its kind conducted in the UK, enabling us to investigate whether perceptions of library staff in the UK are in line with the literature from other countries. The only previous research of this type is the UK is an unpublished master's study by Lo (2004) of student perceptions and expectations of the librarian's reference role, undertaken at the University of Sheffield, but prior to the opening of its stateof-the-art Information Commons in 2007.

The University of Sheffield is the only UK university to have adopted the IC title for one of its learning spaces. The IC is the largest of the University's five library sites, located at the centre of the campus, close to the student union building and to the Western Bank Library (formerly the Main Library). It was developed jointly by the University Library and the institution's Corporate Information and Computing Services (CiCS), in response to the shortage of study spaces and the spatial separation of IT and library areas. It is always open, with self-service facilities allowing use during unserviced hours, when the building is staffed by concierges combining reception, security and portering functions. The IC offers an "integrated learning environment" containing print and electronic resources; a variety of learning spaces, including classrooms, group rooms, silent study areas, informal seating, a "flexispace" with whiteboards, copycams and large plasma screens where students can reconfigure the furniture, and a silent study computer room; and a café (JISC, 2009; Lewis, 2010). Staff are available in the IC during the day on two information desks: library staff provide assistance on the ground floor (Level 0), while CiCS staff offer technical support on the first floor (Level 1) desk (University of Sheffield, 2010). Academic librarians offer an enquiry service on the Level 1 desk during some staffed hours. The IC is currently reviewing the way it supports and engages with learners, including in face-to-face interactions, as part of its Learner Support Programme ${ }^{1}$, making our investigation especially timely.

The other libraries on campus retain a more "traditional" layout and atmosphere, in keeping with the University's research-led mission. The IC houses c100,000 books on all subjects selected to support undergraduate and postgraduate course needs, as well as providing access to e-books, e-journals and other digital resources, but students are expected to draw on the entire 1.5 million volume collection distributed across the system, particularly for background reading and hardcopy backruns of periodicals. The Western Bank Library covers arts and humanities, sciences and most of the social sciences; St George's Library, also located within a few minutes walk from the IC, covers economics, management, information studies, computer science and engineering, supporting departments based in the vicinity; and the two smaller Health Sciences Libraries (based in the nearby Royal Hallamshire Hospital and more distant Northern General Hospital) cover dentistry, medicine and nursing (University of Sheffield, 2011b).

\footnotetext{
${ }^{1}$ Personal communication from Head of Service Development, University Library
} 
The present study aimed to discover how students perceive staff in the IC, with the objectives of understanding how these perceptions influence their use of library resources and whether student perceptions of staff differ between the IC and other library sites. The following research questions were investigated:

- Do students distinguish between the different staff roles in the Information Commons?

- How do students perceive the attitudes and skills of the staff on the information desks in the Information Commons?

- How do students perceive the academic librarians working in the University of Sheffield libraries?

- Is there any difference between student perceptions of staff in the Information Commons and the other libraries?

The study was conducted during the spring and summer of 2010, with most of the investigative work done during the period from June to August. The next section reviews the literature that formed the backdrop for the research and was used to contextualise the results. Subsequent sections outline the methods employed, present the main findings and discuss their significance and implications in relation to previous research. This paper is based on an unpublished masters dissertation (Bickley, 2010), which provides further details of the study.

\section{Literature Review}

\section{Distinguishing between different types of staff}

Hernon and Pastine (1977) found that students struggled to differentiate between distinct categories of library staff. Many believed that academic librarians carried out tasks such as shelving and issuing books, and about half of their respondents did not know whether the person from whom they had sought assistance was a librarian (Hernon \& Pastine, 1977). Fagan (2003, p. 137) similarly found that many students believed that librarians carry out duties usually performed by other workers and about half could not identify which members of staff were librarians. This discovery was also made by Majid and Haider (2008) in a study of the public's view of librarians. Hernon and Pastine (1977, p. 133) found that if students had to make the distinction between librarians and other staff, they would do so on the basis of assumptions that librarians were "older, sitting behind desks, more knowledgeable and competent". This suggests that students do have different perceptions of librarians and other library staff, albeit at least partially based on stereotypes, even if they do not understand which members of staff perform which duties.

Hernon and Pastine (1977) suggest that students do not actually care which staff member helps them, as long as their needs are satisfied. This is echoed by McKinstry and McCracken (2002), who found that students often did not differentiate between librarians and computer support staff on a merged desk, which sometimes made them frustrated at having to queue to get assistance from one staff member while the other was less busy. Students basically expect to be able to seek assistance from any service point or staff member (Brophy, 2005; Lee et al., 2010; Mosley, 2007) and may experience irritation if they are met with an inability to help (McKinstry and McCracken, 2002).

However, Moore and Wells (2009, p. 77) claim that "students learn quickly when to go to which desk", although they do not suggest how this happens. In a different investigation carried out in the same library, students explained that they were "cued" as to which desk they should go to by the "feel" of the staff: staff at the technical support desk were perceived 
to be "younger, busier, less formal, less patient, and more 'techy",, whilst staff at the reference desk were considered “older, quieter, more 'official-looking,' and 'like they might know more"" (Fitzpatrick et al., 2008, p. 236). These perceptions are similar to the assumptions made by some of the students in Hernon and Pastine's (1977) study when attempting to distinguish between librarians and other staff. Gardner and Eng (2005) observed that some students use such perceptions to select which member of staff to approach because they feel more comfortable speaking to someone who looks like a peer.

\section{Perceptions of academic librarians}

Studies have also found that students are unaware of the educational background, skills and job duties of academic librarians. Only a small number in Hernon and Pastine's (1977) study suggested that academic librarians held a master's degree in library science, although $87.1 \%$ believed that librarians had a different educational background to other library staff. Fagan (2003) and Luzius and Noe (2003) report similar findings.

Students appear similarly to be unaware of the skills that academic librarians possess and the professional nature of their work. Hernon and Pastine (1977) found that librarians were generally viewed as having reference or administrative functions. Fagan (2003) similarly found that when asked to identify the duties of academic librarians, students most frequently described reference and circulation duties. In both of these studies, very few students appeared to recognise that academic librarians have a teaching or instructional role (Fagan, 2003; Hernon and Pastine, 1977). However, Polger and Okamoto (2010) found that $66 \%$ of the students in their sample perceived librarians as teachers. They suggest that the contrast with previous studies is due to recent changes in library instruction practices, but do not give specific examples of practices that might have had such an impact (Polger and Okamoto, 2010).

Although the students in Hernon and Pastine's (1977) study emphasised the role of the librarian in helping them to locate resources, later studies found that academic librarians are not seen as a major source of academic assistance. Chiu (2000) surveyed students on their expectations of getting help from their lecturers, teaching assistants, classmates and librarians, and found that librarians were perceived to be the least likely to provide useful help. Lo (2004) also found that students rated librarians poorly, believing them to be unlikely to be able to help. Hardly any of the respondents in Fagan's (2003) study had asked to speak to a librarian when they went to the library. However, Vondracek (2007) found that though students considered librarians to be less likely to be able to help than their tutors, they were just as likely to consult a librarian for help as they were to ask other students.

Thus the extent to which students believe academic librarians can offer academic assistance varies, although all these studies agree that librarians are not considered as the first source of help to approach. There is general agreement that perceptions of academic librarians being unable to provide academic assistance are linked to a lack of awareness about their educational background, duties and professional skills, as previously discussed; if students do not understand that academic librarians are highly qualified and carry out professional duties, they are unlikely to perceive them as being able to help (Chiu, 2000; Fagan, 2003; Green, 1994; Lo, 2004; Luzius and Noe, 2003). It is therefore suggested that librarians need to promote the assistance that they can offer (Chiu, 2000; Fagan, 2003; Hernon and Pastine, 1977; Lo, 2004; Rose, 2009; Schuman, 1990).

Perceptions of staff manner and attitude 
Several studies have investigated the ways in which students view the personal manner of library staff (Fagan, 2003; Hernon and Pastine, 1977; Lo, 2004; OCLC, 2006). Hernon and Pastine (1977, p. 134) found that some students described staff as welcoming, but others felt that library staff "did not want to be bothered", or described feeling "stupid", "embarrassed" or "a nuisance" during interactions with staff. The OCLC (2006) report on student perceptions of library services gathered a similarly mixed response. Sutton et al. (2009) carried out a replication of the OCLC survey and also gathered mixed responses, although a larger number of students reported positive perceptions of staff attitudes than in the OCLC report. Fagan (2003, p. 138) gathered a more positive response, with 75 per cent agreeing that "librarians like helping students" and only a small number reporting that they felt stupid or perceived staff as too busy to help. Thus student perceptions of the manner and attitude of staff vary. Hernon and Pastine (1977) observed that many of the students who described negative perceptions of staff attitudes had had bad experiences of interacting with library staff.

Several authors have investigated the ways that student perceptions of the manner of library staff affect their willingness to interact with them, reporting that when students perceive staff to be unfriendly or unhelpful, they are less likely to seek assistance from them (Fitzpatrick et al., 2008; Onwuegbuzie and Jiao, 1998; Robinson and Reid, 2007). The first of the five components of Bostick's Library Anxiety Scale is "Barriers with the staff", meaning "the idea that library staffs are intimidating and unapproachable" (Robinson and Reid, 2007, p. 408). Onwuegbuzie and Jiao (1998) argue that this is one of the most powerful aspects of library anxiety amongst students. When Robinson and Reid (2007, p. 418) asked students why they did not use the enquiry service, many gave reasons relating to "embarrassment" or "shyness". Fitzpatrick et al. (2008, p. 236) asked students why they did not approach the enquiry desk and similarly found that perceptions of staff caused them to view the desk as a "scary" place. Many, however, explicitly stated that if staff were "friendly" and "positive", their perceptions changed and they felt less embarrassed and intimidated (Fitzpatrick et al., 2008, p. 237).

Robinson and Reid (2007, p. 418) claim that their research showed that shyness about asking for assistance is "more wide spread than libraries might imagine" and Kwon (2008, p. 123) also found library anxiety relating to perceptions of staff to be "prevalent". Robinson and Reid (2007) argue that in order to deal with this issue, academic libraries must promote the enquiry service effectively, ensuring that students understand that providing assistance is what the library staff do.

\section{Library use and perceptions}

Line (1963) observed that familiarity with library staff appeared to reduce reluctance to ask for help and increase perceptions of staff as helpful and knowledgeable. None of the other studies explicitly investigated the effects of frequency of library use on perceptions, although Hernon and Pastine (1977) found that there was no difference between library users and nonusers in their understanding of the educational background and job duties of academic librarians. There thus appears to be some disagreement on whether frequency of library use affects perceptions of staff.

Gardner and Eng (2005) and Dallis and Walters (2006) found that only a very small number of students came to the library with the intention of asking for assistance. Both suggest that this is linked to the availability of "self-service models" of information-seeking and students feeling that they can find what they need by themselves (Dallis and Walters, 2006, p. 257; 
Gardner and Eng, 2005). However, students still expect assistance to be available (Moore and Wells, 2009; Sonntag and Palsson, 2007).

\section{Methodology}

An online questionnaire (using the Kwik Surveys tool) was the primary data collection instrument in this investigation. This method was chosen as the research was conducted during the summer vacation, when many students were expected to be away from the university. Previous studies of this type also used questionnaire surveys. The instrument collected both quantitative and qualitative data through a mix of closed and open questions.

Before being distributed, the questionnaire was piloted with 12 postgraduate students, who were asked to identify any ambiguity or bias in the questions and to comment on their clarity. Their feedback on the wording and layout of both the questions and multiple-choice answers informed the final version, but no changes to the topic or focus of any of the questions were made. The link to the questionnaire was distributed to all University of Sheffield students $(n=24,319)$ via the institutional email system.

Respondents were asked whether they had sought assistance from staff in the IC over the past academic year (2009-10), whether they knew which type of staff they had asked and how they felt about their experiences of asking or not asking for help. They were also questioned on differences between their perceptions of staff at the IC and at other library sites, and how likely they were to approach library staff for assistance with their work. Respondents were then asked to identify how frequently academic librarians carried out specified tasks and what they believed to be their usual educational background, before being questioned about their awareness of the librarians. The complete set of questions and multiple-choice answer options (displayed via drop-down menus) is appended to the paper.

Respondents were invited to leave contact details at the end of the questionnaire if they were willing to be interviewed, on the basis that interviews could provide valuable additional insights into the issues under investigation by enabling more in-depth exploration. They were offered a choice of being interviewed in person or by email; email interviews have recognised limitations, in that the interviewer is reliant on the interviewee's ability to interpret the questions correctly and interviewees may be less willing to give lengthy responses in writing than face-to-face, but represented a pragmatic option for a survey conducted in the summer vacation.

Seven of those indicating their willingness to participate were selected and invited for interview on the basis of having expressed opinions about their experiences of interacting with library staff and having described at least one incident of interaction. However, only one student responded to this invitation and participated in a semi-structured interview via email using critical incident technique (CIT), which allowed relevant issues to be addressed whilst giving the interviewee space to give answers in their own words. The interviewee was asked to describe one incident that had been instrumental in forming their perceptions of IC staff and then asked about their feelings towards staff before and after the incident, and whether it had caused them to change their behaviour in interacting with IC staff. Although the interview evidence was not substantial enough to extend or prove the survey findings (other than anecdotally), the data have been included for completeness and to illustrate the potential of the email-based CIT method for exploring library user experiences. 
Quantitative data from the questionnaire were analysed using the survey tool, with SPSS used for cross-tabulation, then presented using Microsoft Excel. Qualitative data from the questionnaire and interview were analysed into categories by themes according to the question, then presented in charts and tables, using Microsoft Excel where appropriate.

\section{Results}

\section{Sample characteristics}

Two hundred and fifty questionnaire responses were received, representing slightly more than one per cent of the student population. Students of all ages and degree levels participated, although the majority (68\%) were under 25 . Just over half were undergraduates $(129=$ $51.6 \%)$ and slightly more than one quarter were Masters students $(65=26 \%)$. Responses were received from 44 out of the 49 academic departments listed, but the only subject not covered was Russian \& Slavonic Studies, as the other four missing departments were research divisions within the School of Medicine, which arguably should not have been listed separately as students are registered with the School, rather than its sub-divisions. Although the size of the sample was smaller than the 378 responses recommended for a population of 25,000 (Krejcie and Morgan, 1970), it was acceptable for the types of analyses undertaken, which did not use any correlational techniques. Not all questions were answered by all respondents; numbers of respondents are indicated in the narrative and charts.

While the sample covered all disciplines and levels of study, the distribution of undergraduates, Masters and $\mathrm{PhD}$ students does not reflect their proportions in the total student population, where almost three-quarters of students are undergraduate and only 18 per cent are studying at Masters level. Its representativeness was affected by the timing of the survey in the summer vacation, when undergraduate classes had finished, resulting in only four final-year students participating. The results may also have been affected by selfselection bias, in that those who chose to participate in the survey may not be typical of the whole population; for example, Information Studies was over-represented in the sample with 24 participants $(9.6 \%)$, but accounts for less than 2 per cent of the total student population. It is also arguable that infrequent and non-users of the IC may have been less likely to respond to the survey. The research findings are therefore not generalizable beyond the sample surveyed, but readers may identify elements that are transferable to other similar settings.

\section{Seeking assistance in the IC}

All 250 respondents had visited the IC during the past academic year. More than half of the sample claimed to have visited the IC at least weekly, with two to three times per week the most common response here $(67$ participants $=26.8 \%)$. Asking people to recall visits spanning several months is acknowledged as problematic where accurate data are important, but the purpose here was to gain an approximate picture of usage patterns as background to other answers; participants were able to state that their usage varied through the year and 39 $(15.5 \%)$ did so. The most frequently selected reason for visiting was to borrow or return items $(191=76.4 \%)$, but many respondents also selected individual work/study $(163=$ $65.2 \%)$ and group work/study $(109=43.6 \%)$. (Respondents were able to select more than one answer here on the assumption than visits would often have multiple purposes.) The least selected was to ask for help with using library resources $(14=5.6 \%)$. However, most respondents later stated that they had sought assistance from staff in the IC over the past year $(155=62 \%)$. Figure 1 summarises the analysis of free-text responses on the type of assistance described, showing that it was most frequently sought in relation to circulation 
functions $(80$ respondents $=52.6 \%)$ and technical issues $(81=53.3 \%)$. Only three respondents $(2 \%)$ had requested academic assistance.

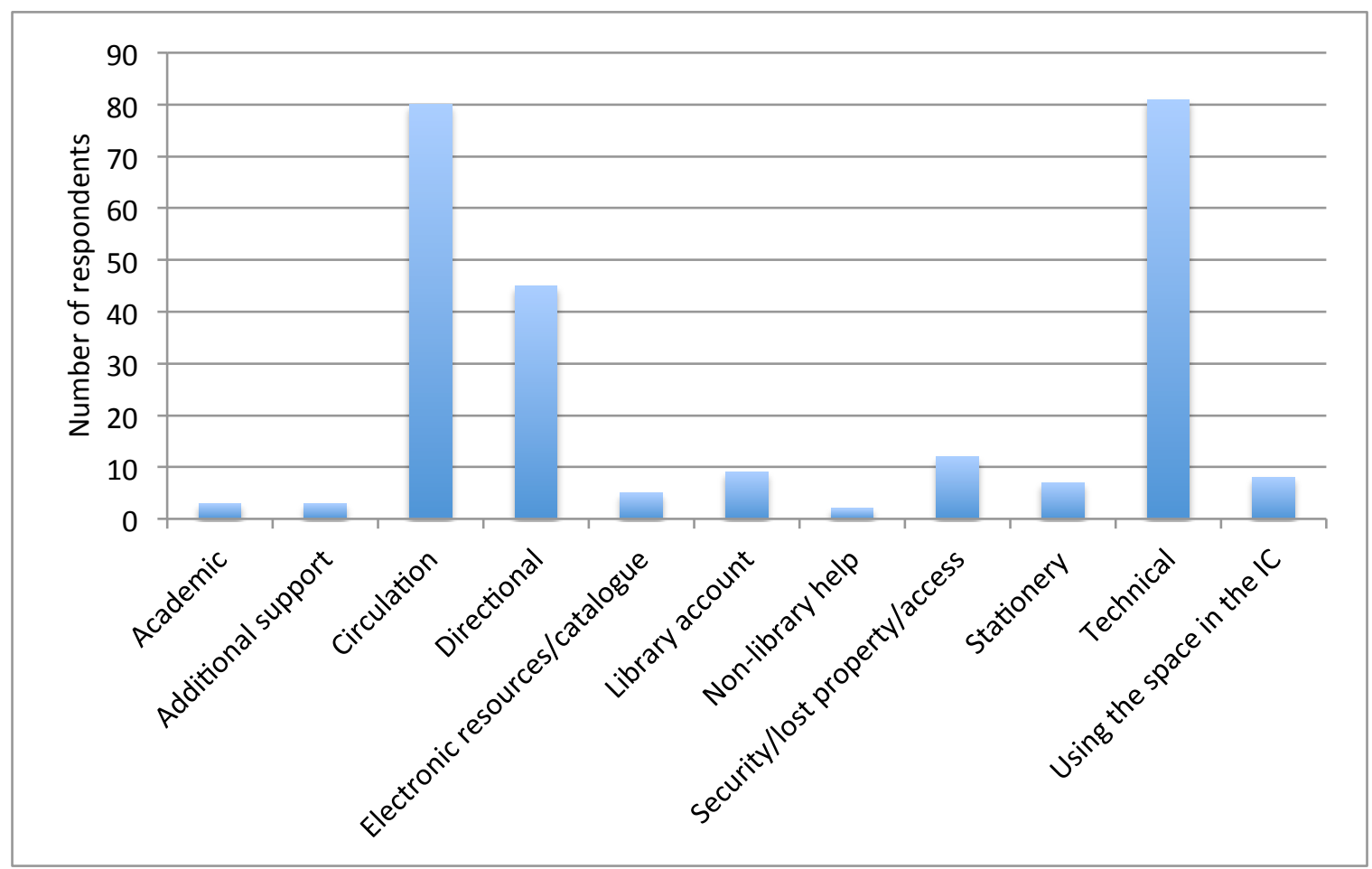

Figure 1. Types of assistance sought $(n=155)$

Respondents were asked if they knew from which type(s) of staff they sought assistance. Figure 2 shows that the most common response (67 respondents) was that they did not know. "Librarian" was selected by 26 students. Of these, only three had asked for specialist or academic help; most had requested assistance with circulation or technical issues. Fifteen of these respondents also selected other kinds of staff members in this answer, even when they had given an example of only one type of assistance sought or a selection of similar kinds of assistance.

\section{Perceptions of staff manner and attitude}

When asked how they felt their questions were dealt with by staff, most comments were positive. One hundred and forty seven respondents answered: 99 (67\% of those answering this question) gave wholly positive feedback and only $15(12 \%)$ made wholly negative comments; neutral or mixed opinions were given by $10(7 \%)$ and $21(14 \%)$ respectively. Positive respondents commented that staff were "helpful" (36 respondents) and "friendly" (11). Respondents also described staff as being "approachable", "polite", "patient", and willing to help. Staff were considered to provide a high level of service (47 respondents), resolving the problem or providing relevant information (18 respondents) in a prompt (16), efficient (10) and clear (9) manner. Staff were also described as being "professional", "knowledgeable" and "well-informed". Negative responses described staff as "unhelpful" (6 respondents), "rude" (5) and "unfriendly" (3); some considered staff to be "abrupt", "irritated", "dismissive", and "sarcastic". Some felt that staff "couldn't be bothered" to help, lacked knowledge and were unable to solve problems or provide clear explanations. Five respondents said that they had been made to feel they were "stupid", or that they should have known the answer. Four described the service offered by staff in the IC as poor or 
unsatisfactory. The student who was interviewed described being given conflicting advice by different members of staff in the IC and was left feeling that "it would be far quicker and less stressful to...simply ask a friend".

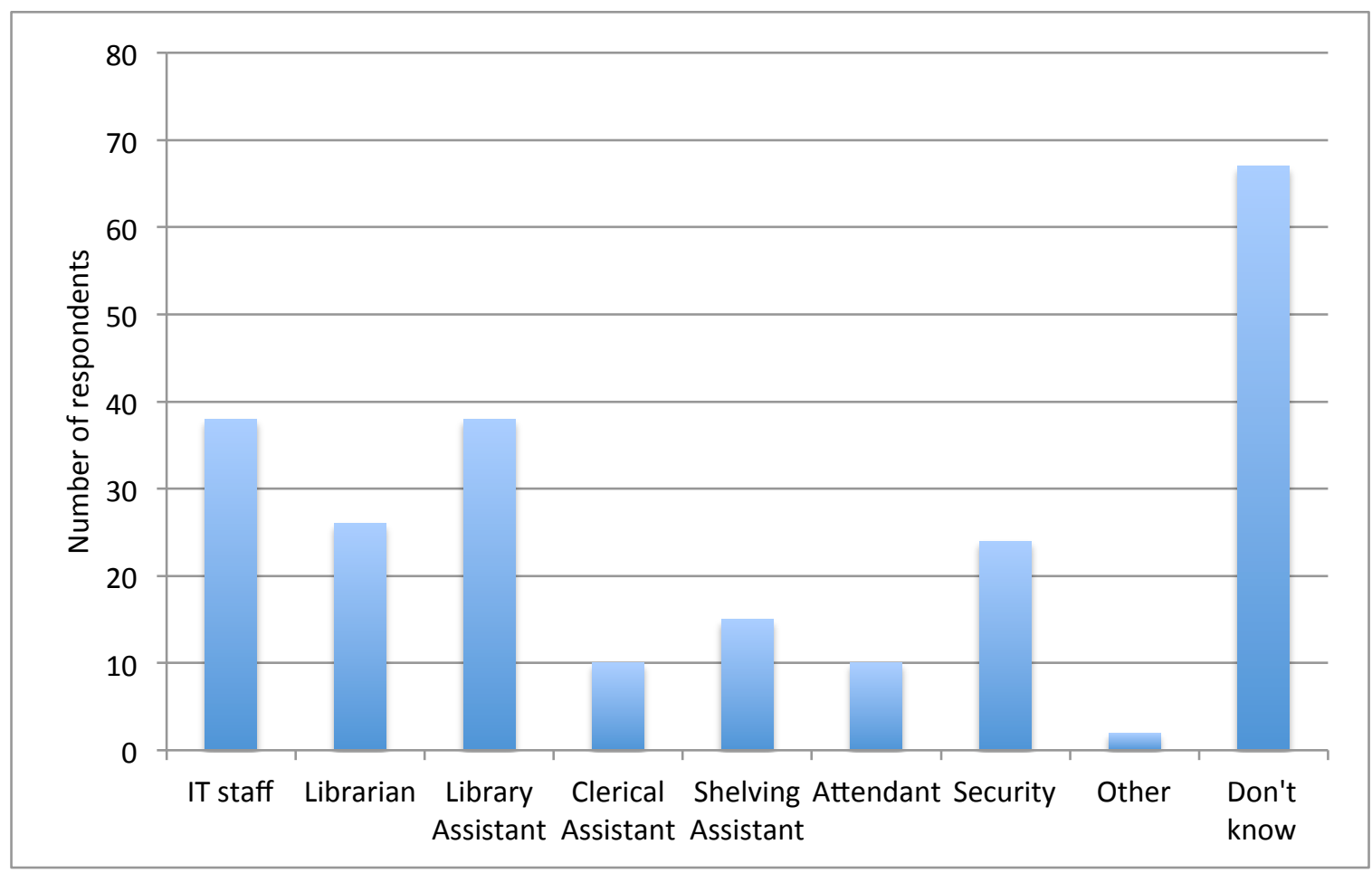

Figure 2. Types of staff asked for help $(n=155)$

Respondents who had sought help remotely by telephone, email or Twitter made similar comments to those describing face-to-face interactions. The method of interaction thus did not seem to have an significant impact on perceptions of staff attitude, but the number of respondents $(38=15.2 \%)$ who reported contacting the IC for assistance remotely was too small to draw firm conclusions here.

\section{Reasons for not seeking help}

Figure 3 shows that the most frequent reason respondents gave for not seeking help was that they did not need to, cited by 119 (47.6\% of participants $=74 \%$ of those answering this question). A small number (17) explained that they did not want to ask for help because of their perceptions of staff: 12 of these respondents specified that their reluctance was based on bad experiences with staff in the IC in the past; these students had found staff to be rude, uninterested or unhelpful and so did not wish to ask for help again. The other five respondents explained that they did not ask for "fear of feeling foolish" or because staff did not appear approachable.

Six respondents described issues related to the way that staff in the IC are located on different desks: three had experienced confusion as to which desk they should approach and one expressed irritation at the desk model.

\section{Seeking assistance elsewhere}

The majority of respondents also used at least one of the other University of Sheffield libraries. Most $(162=65.6 \%)$ did not perceive staff in these libraries any differently to how 
they perceived staff in the IC. A small number described differing perceptions: 16 saw staff in other libraries as being more helpful, friendly, knowledgeable, and "real librarians", in comparison to IC staff who were considered rude, hostile, and "not true library staff". In contrast, eight respondents perceived staff in the other libraries as being unhelpful, impolite and unapproachable, believing the staff in the IC to be more friendly and readily available; one of these respondents suggested that IC staff were more approachable because "they tend to be younger".

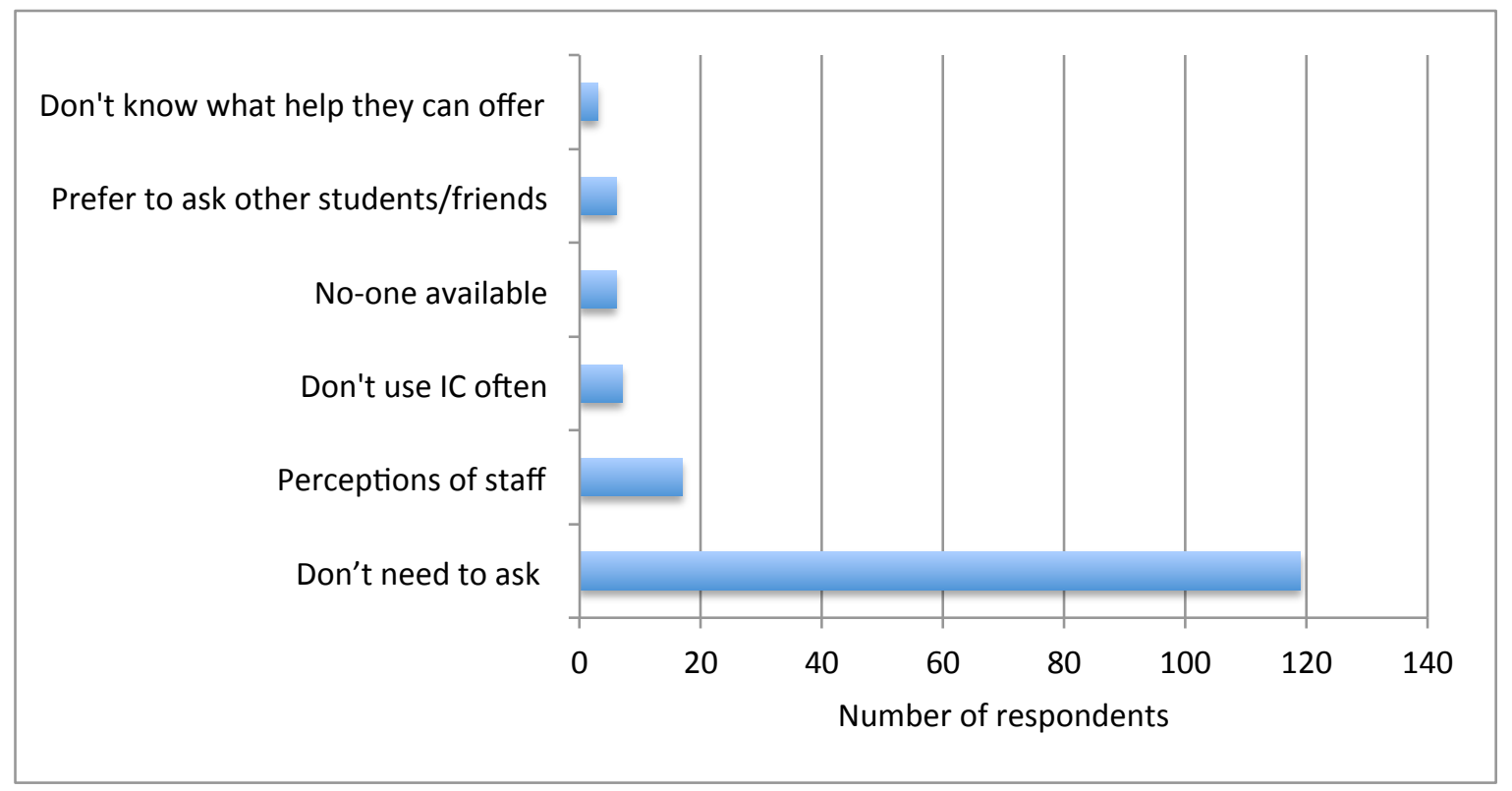

Figure 3. Reasons for not asking for help $(n=152)$

When asked to rank the likelihood of seeking assistance with their work from a tutor/lecturer, other students and library staff, the most popular sources of help for respondents were a tutor/lecturer and other students: 195 respondents (79.6\% of those answering this question) said that they were "Very likely" or "Likely" to ask a tutor or lecturer for help, while 188 $(76.7 \%)$ were "Very likely" or "Likely" to seek assistance from other students. In contrast, only 45 of the 240 respondents $(18.8 \%)$ who gave a ranking here for "Library staff" said that they were "Very likely" or "Likely" to ask library staff for help and almost half $(117=$ $48.8 \%$ ) those who answered stated that they were "Unlikely" to, "Very unlikely" to, or would "Never" seek academic assistance from library staff.

\section{Perceptions of academic librarians}

Respondents were asked to indicate how frequently they believed that academic librarians performed specified duties. Table 1 shows that the tasks most often selected as carried out "Frequently" were those generally performed by library assistants or shelving assistants: putting books back on the shelves $(146$ respondents $=61.6 \%)$ and finding books that students have reserved $(135=57 \%)$. Of the tasks actually carried out by librarians, the one most often suggested as being carried out "Frequently" was purchasing stock, chosen by 64 respondents (27\%). Few respondents believed that librarians "Frequently" teach information and research skills $(35=14.8 \%)$, give subject-specific help to students $(38=16 \%)$ or give general help with their research $(48=20.3 \%)$. A significant number believed that librarians carry out tasks performed by security, cleaning or catering staff, with 54 (22.8\%) suggesting librarians "Frequently" had security duties, 59 (24.9\%) that they "Frequently" cleaned the library and $28(11.8 \%)$ that they "Frequently" worked in the IC café. 
Table 1. Perceived duties of academic librarians $(n=237)$

\begin{tabular}{|c|c|c|c|c|c|}
\hline & Frequently & Sometimes & Rarely & Never & Not sure \\
\hline Putting books back on the shelves & 146 & 50 & 19 & 12 & 10 \\
\hline $\begin{array}{l}\text { Finding books that students have } \\
\text { reserved }\end{array}$ & 135 & 52 & 19 & 11 & 20 \\
\hline Helping students to find books & 98 & 90 & 29 & 7 & 13 \\
\hline Giving general directional help & 96 & 88 & 28 & 9 & 16 \\
\hline $\begin{array}{l}\text { Buying books, journals and } \\
\text { electronic material }\end{array}$ & 64 & 98 & 25 & 7 & 43 \\
\hline $\begin{array}{l}\text { Looking after the computers/ } \\
\text { printers/photocopiers }\end{array}$ & 59 & 83 & 57 & 23 & 15 \\
\hline $\begin{array}{l}\text { Picking up litter/cleaning the } \\
\text { library }\end{array}$ & 59 & 52 & 42 & 59 & 25 \\
\hline Processing fines & 58 & 98 & 39 & 9 & 33 \\
\hline Security & 54 & 37 & 50 & 73 & 23 \\
\hline $\begin{array}{l}\text { Giving general help to students for } \\
\text { research }\end{array}$ & 48 & 76 & 55 & 17 & 41 \\
\hline $\begin{array}{l}\text { Giving subject-specific help to } \\
\text { students for research }\end{array}$ & 38 & 59 & 70 & 27 & 43 \\
\hline $\begin{array}{l}\text { Teaching information/research } \\
\text { skills }\end{array}$ & 35 & 94 & 55 & 12 & 41 \\
\hline Working in the café in the IC & 28 & 31 & 19 & 120 & 39 \\
\hline Removing outdated books & 27 & 96 & 50 & 20 & 44 \\
\hline
\end{tabular}

Respondents were also asked about the minimum educational requirements for an academic librarian. Figure 4 shows that the most popular suggestion was an undergraduate degree in any subject, selected by 48 of the 237 respondents to this question (20.6\%), closely followed by A-Levels ${ }^{2}$ or equivalent $(45=19 \%)$. Thirty-five respondents $(14.8 \%)$ selected a Masters degree in Librarianship, but some of these may have been influenced by the fact that the survey was being conducted by student taking a Masters degree in Librarianship; in addition, 11 of these respondents were among the 24 participants from the Information School, who were likely to have a heightened awareness of the background of a librarian.

Respondents were asked whether they knew the identify of the designated academic librarian for their departments. Just over half of the 237 respondents who answered $(134=56.5 \%)$, did not know. Seventy-one (30\%) were aware of their librarian and the remaining $32(13.5 \%)$ knew that there was a librarian for their department, but did not know who s/he was. Only 19 $(13.1 \%)$ had made contact with their librarian. When asked whether they had attended any inductions or classes run by their academic librarian, 150 of the 237 respondents $(63.3 \%)$ said that they had not; only $74(31.2 \%)$ were able to state that they had done so and $13(5.5 \%)$ did

\footnotetext{
${ }^{2}$ A-Levels are examinations taken in the final year of secondary education to obtain the Advanced Level General Certificate of Education.
} 
not know. However, most of the respondents who had attended such sessions (46 out of 74) had found them useful.

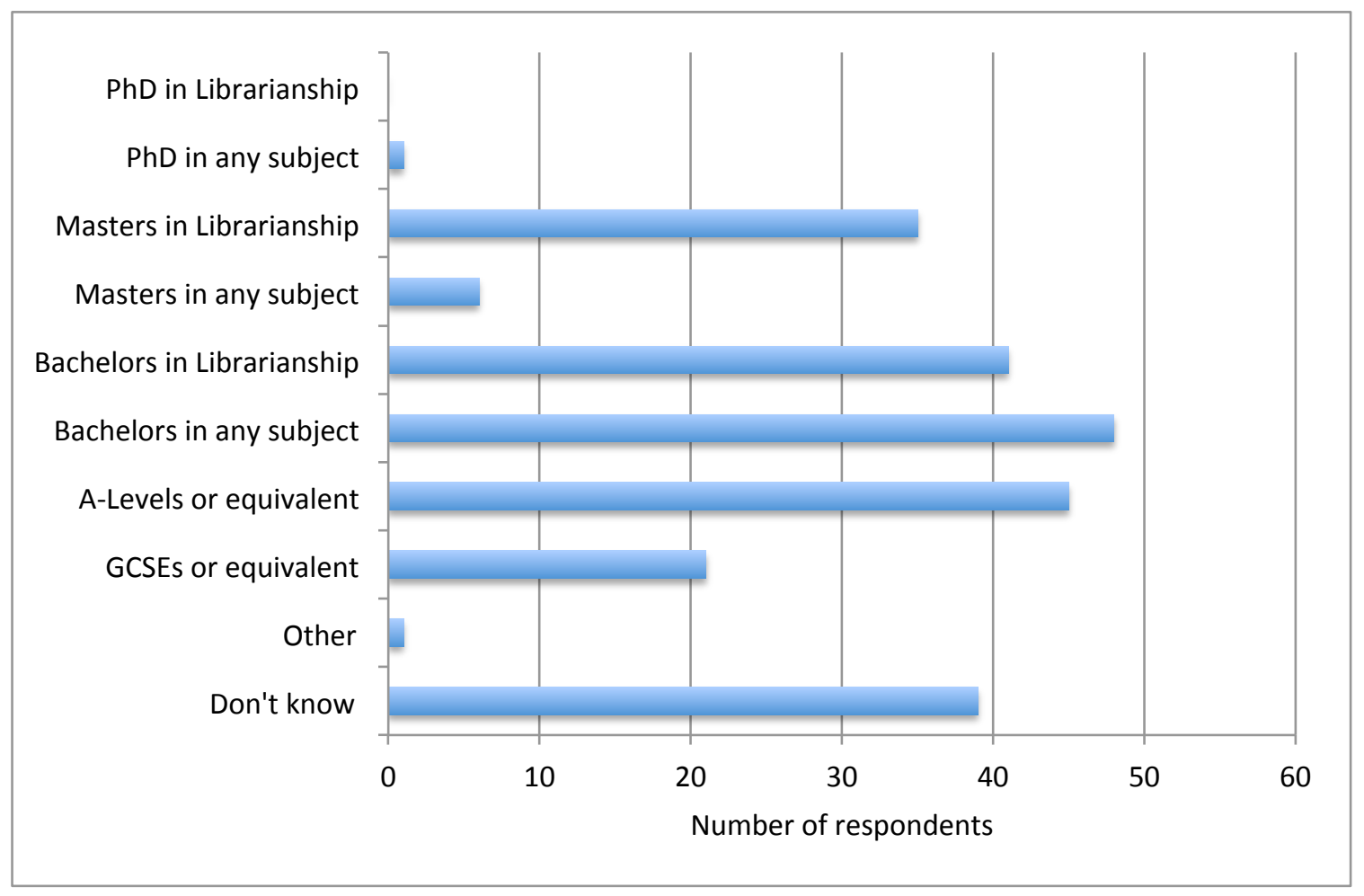

Figure 4. Educational requirements for academic librarians $(n=237)$

\section{Discussion}

Perceptions of staff as sources of assistance

Most respondents did not come to the IC to get help, which is consistent with previous studies (Dallis \& Walters, 2006; Gardner \& Eng, 2005), but the majority had asked for assistance, suggesting that, once there, they recognised a need for help and were willing to ask for it. Most of our respondents held positive perceptions of library staff. No-one described a good level of service alongside poor personal manner, or vice versa, suggesting that student perceptions of library staff attitudes are linked to their perceptions staff skills, although it is not clear which set of perceptions impacts upon the other. These findings support the argument that perceptions of library staff are shaped by experience; only a few students gave neutral answers such as "OK", indicating that most respondents' interactions with staff had led to a positive or negative perception of staff in the IC. The varying perceptions of staff manner are similar to previous findings, but it is important to note that the majority of respondents viewed staff positively, as in Fagan's (2003) research.

A few students were reluctant to seek assistance because they held negative perceptions of IC staff due to bad past experiences, which confirms previous findings that students are less likely to ask for help if they expect staff to be unpleasant or unhelpful (Fitzpatrick, 2008; Onwuegbuzie and Jiao, 1998; Robinson and Reid, 2007). However, our results contradict the claims of Kwon (2008) and Robinson and Reid (2007) that library anxiety relating to perceptions of staff is common among students, as only a very small number said that they did not seek assistance in the IC for this reason. Nevertheless, these comments demonstrate 
that the way in which students are treated can have a powerful impact on their perceptions of staff and on their subsequent use of enquiry services (which was reinforced in the interview, when the student stated that they did not wish to seek assistance from the staff again after an experience that they found unhelpful). These findings echo Hernon and Pastine's (1977) observation that many students with negative perceptions of library staff reported problematic previous experiences.

A few respondents perceived staff in the IC differently to those in other University of Sheffield libraries, commenting that they appeared to be younger than staff in the other libraries; one felt that this made them more approachable, echoing Gardner and Eng's (2005) observation that students prefer to approach a staff member who looks like a peer. However, most respondents perceived staff across all sites similarly. Some linked their differing perceptions to the arrangement of the information desks, saying that they were more inclined to ask for assistance in other libraries because they found the desk easier to locate than those in the IC; a few had experienced confusion when trying to decide which desk they should approach and one suggested that desk signage should be improved. However, the majority appeared to have no major problems with the location and function of the desks, contrasting with McKinstry and McCracken's (2002) observation that students frequently approach the wrong desk for their enquiry and experience irritation when they are re-directed, though this irritation was probably caused more by the long queue described, than by the re-direction per se.

More significantly, only three respondents (2\%) had requested academic assistance and respondents overall ranked library staff poorly as a potential source of such assistance, which is similar to previous findings (Chiu, 2000; Fagan, 2003; Lo, 2004). Respondents were generally unaware of the educational background of academic librarians as in previous studies (Fagan, 2003; Hernon and Pastine, 1977; Luzius and Noe, 2003), which may have contributed to the belief that librarians are not a source of academic assistance, as others have suggested (Chiu, 2000; Fagan, 2003; Green, 1994; Lo, 2004; Luzius and Noe, 2003).

\section{Strategies for dealing with under-utilisation of support}

The continuing failure of students to grasp the academic function of librarians is a serious concern and the persistence of this problem indicates that established methods of promoting their role via library web pages, student inductions and handouts are not enough, even when combined with newer tools such as blogs and RSS feeds; for example, the academic liaison librarians at Sheffield already use blogs to communicate with students about resources for their subjects (University of Sheffield, 2011a). Many librarians are therefore experimenting creatively with different ways of reaching out to students, for example physically taking their reference services to the places where students are and offering on-the-spot research support by roving the floors of their ICs and setting up reference desks in coffee shops and dormitories (Barratt et al., 2010; Moore and Wells, 2009; Dallis and Walters, 2006). Barratt et al. (2010) report success in reaching different students and stimulating research consultations via these methods, though the figures reported showed a relatively small proportion of the total interactions involved academic help.

Some libraries are also reaching out to students virtually, recognising the need either to pull students towards relevant resources by making library websites more compelling, or to push online instruction and resources to students and faculty by introducing more sophisticated search tools. Dallis and Walters (2006) report the implementation of a federated search tool and creation of "class pages" for course assignments at Indiana University Bloomington, both 
on demand and in anticipation of assignments requiring library research. They stress the continual need to explore new ways of delivering services and outline plans to push resources to users through the institutional portal and course management system. The significance and promise of such strategies in the current environment rest on their potential to position libraries and librarians in the academic arena, in the places where students increasingly spend their time (Donaldson, 2010), as well as meeting the identified student preference to have everything in one place (Gardner and Eng, 2005; Zink et al., 2010).

In addition, as Moore and Wells (2009, p. 78) argue, "if students associate a specific librarian with research [or teaching] in a particular discipline or major, they are more likely to seek expert help rather than settle for the best they can do on their own or through asking their friends". However, there is extensive recent evidence from both the UK and US that negotiating access to course websites "owned" by faculty continues to be a major problem for reference and liaison librarians (Corrall and Keates, 2011; York and Vance, 2010).

\section{Perceptions of different staff and their roles}

As in previous studies (Fagan, 2003; Hernon and Pastine, 1977; McKinstry and McCracken, 2002), respondents appeared generally unable to distinguish between the different types of staff working in the IC. Most respondents were unable to identify from which staff they had sought assistance; among those who believed that they had asked a librarian, few reported seeking academic assistance and most had requested help with circulation or technical issues, indicating that many respondents (incorrectly) perceived staff dealing with these aspects of the service as librarians. It is not known how they identified the different roles, but they displayed a similar inability to discriminate when asked how frequently academic librarians carried out particular tasks, with duties such as shelving selected most often, although some respondents did identify tasks such as purchasing material and giving subject-specific assistance as frequent duties of librarians.

Respondents thus displayed confused understanding of the librarians' role, which is consistent with previous findings (Fagan, 2003; Hernon and Pastine, 1977). They showed low awareness of the instructional or teaching responsibilities of academic librarians, which again confirms previous research (Fagan, 2003; Hernon and Pastine, 1977), but contradicts more recent findings (Polger and Okamoto, 2010) and contrasts with the actual situation, as many of the liaison librarians at Sheffield have substantial teaching roles. More than half of the respondents did not know that there was an academic librarian for their department, only a very small number had contacted their departmental librarian for assistance and the majority claimed not to have attended any sessions run by their librarian, with some volunteering that they did not know the librarians ran classes. However, it is possible that students may have attended such sessions without realising that the person delivering it was a librarian (for example, if it was part of their normal academic timetable). Most respondents who had attended sessions run by their librarian considered them useful, indicating a generally positive view of the instruction offered, once students had been exposed to it.

At one level, the inability here of students to differentiate between librarians, paraprofessionals and students assistants simply confirms a longstanding problem (Hernon and Pastine, 1977; Fagan, 2003) and might suggest that librarians just need to be more innovative and imaginative if they want to change the misperceptions identified. Another interpretation might view our findings as representing a step backwards, with students confusing librarians not only with other library staff, but also with different functions, including roles with lower educational qualifications (such as security, cleaning and 
catering). However, this kind of thinking is unlikely to lead to creative solutions as it fails to recognise important dimensions of the contemporary one-stop shopping environment.

\section{Strategies for delivering support in multi-functional environments}

The fact that only around half of our sample thought librarians never worked in the cafe, does not necessarily mean that students held them in low regard, but instead can be seen as a reflection of their expectation that they can get any type of help from any service point or staff member (Brophy, 2005; Lee et al., 2010; Mosley, 2007). The findings of the Undergraduate Research Project at the University of Rochester are pertinent here: the Rochester team found students wanted staff support, but ideally a person who could do everything!

"Students rarely make distinctions between the types of staff needed in the library. Instead, they include a generic staff person who is expected to provide reference assistance, check out materials, answer IT questions, and brew a great latte." (Foster and Gibbons, 2007, p.25)

One motivation of the Rochester study was to work out how to get more students to come to the desk for help, to restore the specialist, expert, informed, personalised face-to-face service that attracted so many librarians to their profession. Their survey and interviews revealed that if students need expert advice, they turn to their instructors or - interestingly - to their families, whom they phone or email. Foster and Gibbons (2007) concluded that a collaborative service approach might work better in an environment where students want everything together, with multiple staff at the same desk cross-referring questions to each other. A preference for personalised one-stop shopping also emerged from students' ideas for improving the Rochester library website, when they suggested adding links to their professors and course websites, as well as other campus services (Foster and Gibbons, 2007).

The issue of separate versus integrated help desks is a key theme of the literature on IC environments. Gardner and Eng (2005, p. 415) argue that combining reference assistance with a technology help point "offers opportunities to bring students closer to the reference desk and librarians", as well as reflecting their preference for one-stop shopping. In addition, providing a tiered service at a desk staffed by both student assistants and librarians may generate more reference enquiries, as students seem more comfortable approaching students workers as their peers, who can then refer relevant queries to librarians (Gardner and Eng, 2005).

Sinclair (2009, p. 507) similarly favours transforming the reference desk into a "technology and learning desk... [a] centralized, blended service point" where peer mentors (student assistants), blended librarians (with IT and educational skills) and IT staff "provide impromptu hands-on learning opportunities". Zink et al. describe encouragingly high levels of collaborative one-stop problem-solving and shared learning through student workers and different professions (library, IT and media) working as partners at their multi-functional @One desk at the University of Nevada. In contrast to the somewhat disparaging Rochester depiction of one-stop shopping as a "mommy model of service", they liken this style of onestop service - a "team approach to problem solving" - to "the freewheeling work environment characteristic of leading knowledge firms" (Zink et al, 2010, p. 118), which is a much more attractive justification of the departure from the traditional specialist reference desk model. However, Fitzpatrick et al. (2008) make a good case for a dedicated Reference 
and Research Assistance Desk in a commons environment, providing evidence that this model can work better for both users and librarians in a large research library.

Foster and Gibbons (2007, p. 77) also see collaboration with academic staff as another way of promoting the reference role of librarians, suggesting that librarians should "pursue better partnerships with teaching faculty, so that professors invite librarians into their departments and classrooms and explicitly direct their students to approach librarians for bibliographic support”.

\section{Conclusion}

Many findings from the present investigation are consistent with those of previous studies, suggesting that student perceptions of academic library staff have not changed significantly over time, despite considerable transformations in the resources, services, facilities and activities of academic libraries. Most of the comments on staff attitudes and competence were positive, but our study revealed a continuing failure by students to recognise different staff functions and expertise, in particular the academic roles and affiliations of librarians, resulting in poor use of the support offered, which reflects a general problem of underutilisation of specialist help reported in the literature. Although IC settings have simplified the situation by consolidating provision in one location, the proliferation of services and the combination of physical and virtual learning environments have complicated matters.

IC environments have enabled library, technology and other services to be brought together in different models of collaborative provision. Sheffield offers an integrated learning environment with separated help desks for technical and reference assistance, which seems to meet the needs of most users, though a few students had experienced confusion with the location and function of the desks. Other libraries have experimented with merged and tiered help desks, arguing that integrated services typically generate more enquiries from one-stop shoppers, especially when student assistants are involved in the partnership supporting their peers; though separate, specialist, reference and research assistance services have also proved successful in research-led IC settings.

Librarians have also recognised the need to reach out both physically and virtually to make students aware of the support they can provide by offering help in different locations at the point of need. Stronger partnerships with academic staff are even more critical in this context as institutions step up their use of virtual learning environments and course websites. The goal now for academic librarians - at Sheffield and across the sector - must be to secure a permanent prominent presence in the online classroom, in addition to the traditional lecture or seminar room, aiming to position their subject-related support and research assistance alongside the learning resources provided by teaching faculty, which should lead to more frequent and productive engagement with students in both virtual and physical spaces.

Further investigation of the issues discussed here at other institutions with modern technology-rich commons environments would allow comparisons to be made and firmer conclusions to be drawn. It would also be useful to explore through interviews at Sheffield and elsewhere several aspects of student perceptions not covered by the present study, such as how students decided which desk to approach for help and whether their assumptions about the educational background of librarians affected their perceptions of their ability to provide academic support. 


\section{Acknowledgements}

The authors gratefully acknowledge the contribution of all the students who participated in this research and the co-operation and support of library and computing staff in facilitating the study.

\section{References}

Abson, C. (2003), "The changing picture of higher education", in Oyston, E. (Ed.), Centred on Learning: Academic Case Studies on Learning Centre Development, Ashgate, Aldershot, pp. 1-18.

Beagle, D. (1999),"Conceptualizing an Information Commons", Journal of Academic Librarianship, Vol. 25 No.2, pp. 82-89.

Bennett, S. (2005). "Righting the balance", in CLIR, Library as Place: Rethinking Roles, Rethinking Space, Council on Library and Information Resources, Washington DC, pp. 10-24, available at: http://www.clir.org/pubs/reports/pub129/pub129.pdf (accessed 26 October 2010).

Bewick, L. and Corrall, S. (2010), "Developing librarians as teachers: a study of their pedagogical knowledge", Journal of Librarianship and Information Science, Vol. 42 No. 2, pp. 97-110.

Bickley, R. (2010), An Investigation into Student Perceptions of Staff in the Information Commons at the University of Sheffield, Masters Dissertation, University of Sheffield, Sheffield, available at: http://dagda.shef.ac.uk/dispub/dissertations/200910/External/Rbickley bickley_090125085.pdf (accessed 4 February 2011).

Bodnar, J. (2009), "Information and learning commons, faculty and student benefits", New Library World, Vol. 111 No. 9/10, pp. 403-409.

Boyd, R. (2008), "Staffing the Commons: job analysis in the context of an Information Commons", Library Hi Tech, Vol. 26 No. 2, pp 232-243.

Brophy, P. (2005), The Academic Library, 2nd ed.. Facet, London.

Chiu, H. L. (2000), "Seeking help in Hong Kong's academic libraries", OCLC Systems \& Services, Vol. 16 No. 4, pp. 181-188.

Corrall, S. and Keates, J. (2011), "The subject librarian and the virtual learning environment: a study of UK universities", Program, Vol. 45 No. 1, pp. 29-49.

Cowgill, A., Beam, J. and Wess, L. (2001), "Implementing an Information Commons in a university library", Journal of Academic Librarianship, Vol. 27 No. 6, pp. 432-439.

Dallis, D. and Walters, C. (2006), "Reference services in the commons environment", Reference Services Review, Vol. 34 No. 2, pp. 248-260.

Donaldson, A. (2010), "Delivering legal information skills via a VLE”, Legal Information Management, Vol. 10 No. 2, pp. 81-85.

Fagan, J. (2003), "Students' perceptions of academic librarians", The Reference Librarian, Vol. 37 No. 78, pp. 131-148.

Fitzpatrick, E. B., Moore, A. C. and Lang, B. W. (2008), "Reference librarians at the reference desk in a Learning Commons: a mixed methods evaluation", Journal of Academic Librarianship, Vol. 34 No. 3, pp. 231-238.

Foster, N.F. and Gibbons, S. (eds.) (2007), Studying Students: The Undergraduate Research Project at the University of Rochester, Association of College and Research Libraries, Chicago. 
Franks, J. A. (2008), "Introducing Learning Commons functionality into a traditional reference setting", E-JASL: The Electronic Journal of Academic and Special Librarianship, Vol. 9 No. 2, available at: http://southernlibrarianship.icaap.org/content/v09n02/franks_j01.html (accessed 26 October 2010).

Gardner, S. and Eng, S. (2005), "What students want: Generation Y and the changing function of the academic library", portal: Libraries and the Academy, Vol. 5 No.3, pp. 405-420.

Green, T. (1994), "Images and perceptions as barriers to the use of library staff and services", New Library World, Vol. 95 No. 7, pp. 19-24.

Held, T. (2009), "The information and learning commons: a selective guide to sources", Reference Services Review, Vol. 37 No. 2, pp. 190-206.

Hernon, P. and Pastine, M. (1977), "Student perceptions of academic librarians", College \& Research Libraries, Vol. 38 No.2, pp. 129-139.

JISC. (2009), Planning and Designing Technology-Rich Learning Spaces: University of Sheffield, Information Commons, available at: http://www.jiscinfonet.ac.uk/infokits/learning-space-design/more/casestudies/sheffield/index html2 (accessed 26 October 2010).

Krejcie, R.V. and Morgan, D.W. (1970), "Determining sample size for research activities", Educational and Psychological Measurement, Vol. 30 No. 3, pp. 607-610, available at: http://opa.uprrp.edu/InvInsDocs/KrejcieandMorgan.pdf (accessed 4 February 2011).

Kwon, N. (2008), "A mixed-methods Investigation of the relationship between critical thinking and library anxiety among undergraduate students in their information search process", College \& Research Libraries, Vol. 69 No. 2, pp. 117-131.

Lee, M., Ritterbush, J. and Sivigny, R. (2010), "Reference at the commons: a case study", Reference Services Review, Vol. 38 No. 1, pp. 81-89.

Lewis, M. (2010), "The University of Sheffield Library Information Commons: a case study", Journal of Library Administration, Vol. 50 No. 2, pp. 161-178.

Line, M. B. (1963), "Student attitudes to the University Library: a survey at Southampton University", Journal of Documentation, Vol. 19 No. 3, pp. 100-117.

Lo, C. (2004), Students' perceptions of librarians and expectations of their assistance with academic work - with reference to an academic library in Sheffield, Unpublished dissertation, University of Sheffield.

Luzius, J. and Noe, N. (2003), "Do they know who we are? Student perceptions of university librarians", Alabama Librarian, Vol. 53 No. 2, pp. 13-16.

MacWhinnie, L. A. (2003), "The Information Commons: the academic library of the future", portal: Libraries and the Academy, Vol. 3 No. 2, pp. 241-257.

Majid, S. and Haider, A. (2008), "Image problem even haunts hi-tech libraries: stereotypes associated with library and information professionals in Singapore", Aslib Proceedings, Vol. 60 No. 3, pp. 229-241.

McKinstry, J. and McCracken, P. (2002), "Combining computing and reference desks in an undergraduate library: a brilliant innovation or a serious mistake?", portal: Libraries and the Academy, Vol. 2 No. 3, pp. 391-400.

Moore, A. C. and Wells, K. A. (2009), "Connecting 24/5 to Millennials: providing academic support services from a Learning Commons", Journal of Academic Librarianship, Vol. 35 No. 1, pp. 75-85.

Mosley, P. A. (2007), "Assessing user interactions at the desk nearest the front door", Reference \& User Services Quarterly, Vol. 47 No. 2, pp. 159-167. 
Norry, J. (2003), "The changing staff experience", in Oyston, E. (Ed.), Centred on Learning: Academic Case Studies on Learning Centre Development, Ashgate, Aldershot, pp. 5795.

OCLC (2006), College Students' Perceptions of Libraries and Information Resources, available at: http://www.oclc.org/reports/pdfs/studentperceptions.pdf (accessed 26 October 2010).

Onwuegbuzie, A. J. and Jiao, Q. G. (1998), "Understanding library-anxious graduate students", Library Review, Vol. 47 No. 4, pp. 217-224.

Polger, M. A. and Okamoto, K. (2010), "“Can't anyone be a teacher anyway?" Student perceptions of academic llbrarians as teachers", Library Philosophy and Practice, March, pp. 1-16, available at: http://www.webpages.uidaho.edu/ mbolin/polgerokamoto.pdf (accessed 26 October 2010).

Roberts, R. L. (2007), “The evolving landscape of the learning commons", Library Review, Vol. 56 No. 9, pp. 803-810.

Robinson, C.M. and Reid, P. (2007), “Do academic enquiry services scare students?”, Reference Services Review, Vol. 35 No. 3, pp. 405-424.

Rose, S. (2009), "Student views on library services: key lessons for developing libraries of the future", SCONUL Focus, Vol. 47, pp. 4-6, available at http://www.sconul.ac.uk/publications/newsletter/47/2.pdf (accessed 26 October 2010)..

Schuman, P. G. (1990), “The image of librarians: substance or shadow?”, Journal of Academic Librarianship, Vol. 16 No. 2, pp. 86-89.

Sonntag, G. and Palsson, F. (2007), "No longer the sacred cow - no longer a desk: transforming reference service to meet 21 st century user needs", Library Philosophy and Practice, February, pp. 1-16, available at:

http://www.webpages.uidaho.edu/ mbolin/sonntag-palsson.pdf (accessed 26 October 2010).

Sutton, L., Bazirjian, R. and Zerwas, S. (2009), "Library service perceptions: a study of two universities", College \& Research Libraries, Vol. 70 No. 5, pp. 474-495.

University of Sheffield. (2010), Staffed services, available at: http://www.shef.ac.uk/infocommons/students/gettingstarted/staffedservices.html (accessed 26 October 2010).

University of Sheffield (2011a), The University Library: Faculty liaison blogs, available at: http://www.shef.ac.uk/library/services/blogs.html (accessed 4 February 2011),

University of Sheffield (2011b), The University Library: Libraries and collections, available at: http://www.shef.ac.uk/library/collections (accessed 4 February 2011).

Vondracek, R. (2007), "Comfort and convenience? Why students choose alternatives to the library", portal: Libraries and the Academy, Vol. 7 No. 3, pp. 277-293.

Whitchurch, M. J., Belliston, C. J. and Baer, W. (2006), "Information Commons at Brigham Young University: past, present, and future", Reference Services Review, Vol. 34 No.2, pp. 261-278.

York, A.C. and Vance, J.M. (2009), "Taking library instruction into the online classroom: best practices for embedded librarians", Journal of Library Administration, Vol. 49 No. 1/2, pp. 197-209.

Zink, S.D., Medaille, A., Mundt, M., Colegrove, P.T. and Aldrich, A. (2010), “The @One service environment: information services for and by the millennial generation", Reference Services Review, Vol. 38 No. 1, pp. 108-124. 


\section{Professional biographies}

Rachel Bickley graduated with a BA in English from the University of York and then worked as a Graduate Trainee at Leeds Metropolitan University Library. She completed her MA in Librarianship at the University of Sheffield in 2010 and is currently working as an Assistant Librarian at the University of the West of England in Bristol. She is also involved in supporting colleagues through the LIS New Professionals Network in the UK.

Rachel Bickley can be contacted at rachel.bickley@uwe.ac.uk

Sheila Corrall is Professor of Librarianship \& Information Management and Head of the Libraries \& Information Society Research Group at the University of Sheffield Information School. Her previous positions have included Director of Academic Services at the University of Southampton, University Librarian at the University of Reading and Director of Library \& Information Services at Aston University. She was the first President of the Chartered Institute of Library and Information Professionals (CILIP, established in 2002) and currently serves on the National Committee of its University College \& Research Group. Sheila Corrall can be contacted at s.m.corrall@sheffield.ac.uk. 